\title{
Homeopathic drugs to control red rot disease in sisal plants
}

\author{
Erasto V. S. Gama • Franceli Silva • Ivanete Santos • \\ Ricardo Malheiro • Ana Cristina Fermino Soares • \\ José Alberto Pereira • Cintia Armond
}

Accepted: 10 September 2014 / Published online: 17 October 2014

(C) INRA and Springer-Verlag France 2014 could be a good strategy to control Aspergillus niger incidence in sisal plants.

Keywords Sisal $\cdot$ Sisal red rot $\cdot$ Homeopathy $\cdot$ Dynamizations

\section{Introduction}

Sisal (Agave sisalana Perrine ex. Engelm), from the Agavaceae family, is a plant originated from Northern and Central America, being cultivated in tropical countries. This herbaceous monocotyledonous plant is widely cultivated in Brazil and Tanzania, two of the most important producing countries. Worldwide and according to the most recent statistics from Food and Agriculture Organization (FAO) 428,104 ha of sisal are cultivated, with a production of 40,965 t of vegetable hard fibre (FAO STAT 2014), its main product. In Brazil, sisal is an important crop in diversified aspects, being cultivated in Paraíba, Rio Grande do Norte, and Bahia states, concentrating Bahia $95.53 \%$ of Brazilian sisal cultivation (IBGE SIDRA 2014) totalizing 248,683 ha of cultivated area (FAO STAT 2014), more than $50 \%$ of worldwide area, producing about $89,128 \mathrm{t}$ of sisal plant (FAO STAT 2014). Socially and economically, sisal crop has a tremendous impact in Brazilian states. More than 0.5 million workers depend on sisal, from cultivation to processing industry. Economically, fibres from nonwood plants are more valuable than fibres from wood plants for paper making (Gutiérrez et al. 2008), representing a high added value to sisal plant. Sisal fibres are also applied in craftsmanship and for textile industry, while unprocessed leaves are used for animal feed.

Meanwhile, sisal plant is affected by pests and diseases, Scyphophorus acupunctatus Gyllenhal (Coleoptera: Curculionidae) is the main insect pest, while sisal plant can be infected by Korogwe leaf spot, zebra disease (caused by Phytophthora nicotianae), dieback disease, and the most 
destructive of all in Brazilian plantations the bole rot or red rot, caused by Aspergillus niger Thieg. This pathogenic agent is contributing to the continuous decrease in sisal plantation in semi-arid region of Bahia in Brazil, and in many areas, it already witnessed the crop abandonment due to high disease incidence. Once infected by Aspergillus niger, bole from sisal plant starts to rot (Fig. 1). Plant internal tissues become brown, being surrounded by a reddish border (Fig. 1e). After some months, the plant meristem is completely affected, interrupting the communication between the bole and leaves, becoming leaves yellow (Fig. 1b, c) collapsing when bole is completely rotten, causing plant death. According to Coutinho et al. (2006) disease incidence can vary between 5 and $40 \%$ in the producing areas, a data that can keep growing without proper strategies of control.

The application and introduction of homeopathic drugs in the control of plants phytopathogenic agents, viruses, bacteria, nematodes, and even insect pests are already a reality with plausible results in vitro and in planta trials as well (Betti et al. 2009; Toledo et al. 2011; Wyss et al. 2010), even with a high level of scepticism by academic scientific sector (Betti et al. 2013). Homeopathic drugs revealed to be effective among diversified phytopathogenic fungus in several crops of economic importance: Botryodiplodia in guava fruit (Kehri and Chandra 1986), control of Aspergillus niger in coriander and cumin Mishra (1983), blight of cotton caused by Xanthomonas campestris pv. malvacearum (Javed et al. 2013), betelvine disease caused by Phytophthora parasitica var. piperina (Chaurasia and Vyas 1997) and Arabidopsis thaliana infected with Pseudomonas syringae (Shah-Rossi et al. 2009). In this sense, homeopathic drugs could be exploited as a possible way to control the incidence of Aspergillus niger in sisal plants.

Based on the previous aspects, the present work intends to study the potentialities of five different homeopathic drugs
(Carbo vegetabilis, Ferrum metallicum, Natrum muriaticum, phosphorus and sulphur) at different centesimal Hahnemannian $(\mathrm{CH})$ dynamizations applied $(3 \mathrm{CH}, 5 \mathrm{CH}$, $7 \mathrm{CH}, 9 \mathrm{CH}$ and $12 \mathrm{CH}$ ) in vitro and in planta, for the control of Aspergillus niger, the causal agent of red rot of sisal plant. The type of homeopathic drug and their effect according to the centesimal dynamization applied are optimized to a better strategy to control Aspergillus niger incidence in sisal plants.

\section{Material and methods}

\subsection{Homeopathic drugs tested and Aspergillus niger source}

The homeopathic drugs selected for the present study were Carbo vegetabilis, Ferrum metallicum, Natrum muriaticum, phosphorus and sulphur. The homeopathic drugs were selected based on their efficacy on controlling species of fungus, especially Aspergillus sp., as well as for other aspects considered by Casali et al. (2009). The isolates of Aspergillus niger used in the present study were obtained from the culture collection of the Federal University of Recôncavo da Bahia (UFRB) with the voucher number NA 131.

\subsection{Preparation of homeopathic dynamizations}

Homeopathic drugs were purchased in a specialized homeopathic pharmacy at a dynamization of $2 \mathrm{CH}$ (centesimal Hahnemannian). Dynamizations of 3, 5, 7, 9 and $12 \mathrm{CH}$ were prepared in the Phytochemistry and Agroecology Laboratory of the UFRB, according to the guidelines of the Brazilian Homeopathic Pharmacopeia (FHB 2011). Dynamizations were prepared in a "mechanical-arm" device model (Denise 50 , Autic) with ethanol $(70 \%)$. All dynamizations of all homeopathic drugs were prepared immediately after use.
Fig. 1 Sisal (Agave sisalana) and Aspergillus niger incidence: healthy plant (a), sisal plants with initial (b), intermediate (c) and advanced symptoms (d); sisal bole rot and red rot (e); death sisal plant with bole rot (f); and Aspergillus niger in PDA (potato dextrose agar) medium (g). Bole from sisal plants start to rot when infected by $A$. niger. Bole becomes brown, being surrounded by a reddish border. When completely rot, leaves turn yellow, collapse and plant dies






\subsection{In vitro assays}

The experimental outline was completely randomized with six different treatments (the five homeopathic drugs at different dynamizations, plus the control treatment). The control treatment was carried out simultaneously using distilled water instead of homeopathic drug. Each treatment was carried out in quadruplicate.

Each homeopathic drug at the different dynamizations was added to potato dextrose agar (PDA) medium at a concentration of $0.005 \%$ accordingly to the methodology described by Bonato et al. (2006). After solidification, Aspergillus niger was inoculated in the medium and maintained at $28 \pm 2{ }^{\circ} \mathrm{C}$ until a complete growth of Aspergillus niger in the petri dish of one of the treatments applied (control treatment after 12 days at the considered conditions).

\subsection{Evaluated parameters}

\subsubsection{Mycelia growth and sporulation}

Mycelia growth was taken each two days until the end of the assay (12 days), being measured the colony diameter at two perpendicular positions.

Aspergillus niger sporulation was determined from the count of spores produced in petri dish containing the different homeopathic drugs at different dynamizations and control treatment. Conidia from each plate were harvested at 12 days post-inoculation by suspending spores in $20 \mathrm{~mL}$ of distilled water with Tween 20. Conidial concentration (conidia per $\mathrm{cm}^{2}$ mycelia ${ }^{-1}$ ) was counted using a Neubauer haemocytometer under a CTR 5000 light microscope (Leica).

\subsubsection{Conidium germination}

The percentage of germinated conidia was determined for each homeopathic drug at different dynamizations and respective control treatment. For conidia germination of Aspergillus niger, the homeopathic drugs were added to PDA medium in a concentration of $0.005 \%$. Afterwards in microplates, $150 \mu \mathrm{L}$ of medium containing the homeopathic drugs at different dynamizations and $150 \mu \mathrm{L}$ of Aspergillus niger conidia suspension at $1 \times 10^{7}$ conidia $\mathrm{mL}^{-1}$ ) were incubated at $37^{\circ} \mathrm{C}$ for $17 \mathrm{~h}$. Passed the incubation period, lactophenol was added to each well to stop conidia germination, and germinated conidia were counted from a total of 200 spores. Only the conidia with germ tubes twice longer than their width were considered to have germinated.

\subsection{In planta assays}

In planta assays were selected the best dynamizations of each homeopathic drug tested in vitro based on mycelia growth, germination and sporulation of Aspergillus niger. In planta assays were carried out in greenhouses at UFRB in randomized experimental blocks with six treatments (each homeopathic drug at best dynamization and control treatment) each with four replicates (each replicate with six sisal plants).

Sisal plants were reproduced by vegetative means with bulbils collected from the semi-arid region of Bahia (Brazil) and maintained in greenhouses. Eight months after cultivation, homeopathic drugs at best dynamization were applied over sisal plants: $50 \mathrm{~mL}$ of homeopathic drug diluted in water (six drops per litre of irrigation water). The application of the homeopathic drugs was carried out during 15 continuous days. The control treatment was applied by irrigation water during the same period and at the same quantity.

After the application period of homeopathic drugs, Aspergillus niger from the same isolate used for in vitro assays was inoculated in sisal plants. Two incisions $(2 \mathrm{~cm}$ deep and $1 \mathrm{~mm}$ of diameter) were made in the plant bole, and the pathogen was introduced in the plant: $2 \mathrm{~mL}$ of Aspergillus niger suspension adjusted to $1 \times 10^{7}$ conidia $\mathrm{mL}^{-1}$.

\subsubsection{Disease incidence and severity}

One month after Aspergillus niger inoculation, red rot incidence and disease severity were assessed. Disease incidence was calculated according to the number of plants with and without symptoms of red rot.

To evaluate disease severity, sisal plants were removed from the plantation site, and cross-sectional cuts were made to evaluate the disease severity according to a scale proposed by Sá (2009): 0 - no disease symptoms; 1 -initial symptoms, rot at the base of the external leave; 2 -advanced symptoms, rot inside the plant still alive; and 3-dead plant, bole completely rot.

Data from severity was transformed in a disease severity index (DSI) according to McKinney (1925):

$D S I=\frac{\sum(\text { scale grade } \times n) \times 100}{\sum \text { plants } \times \text { maximum scale grade }}$

2.6 Statistical treatment

\subsubsection{Analysis of variance}

An analysis of variance (ANOVA) with type III sums of squares was performed using the general linear model (GLM) procedure of the SPSS software, version 21.0 (IBM Corporation, NY, USA). The fulfilment of the ANOVA requirements, namely the normal distribution of the residuals and the homogeneity of variance, was evaluated by means of the Kolmogorov-Smirnov with Lilliefors correction (if $n>50$ ) 
or the Shapiro-Wilk's test (if $n<50$ ) and the Levene's tests, respectively. All dependent variables were analyzed using a one-way ANOVA with or without Welch correction, depending if the requirement of the homogeneity of variances was fulfilled or not. The main parameters studied were the effect of homeopathic drugs at different dynamizations in growth inhibition, spores formation and germination of Aspergillus niger in vitro comparatively to control treatment. In planta, the application of each homeopathic drug at best dynamization was compared by disease incidence and disease severity index. If a statistical significant effect was found, means were compared using Tukey's honestly significant difference multiple comparison test or Dunnett's T3 test also depending if equal variances could be assumed or not. All statistical tests were performed at a $5 \%$ significance level.

\section{Results and discussion}

\subsection{Aspergillus niger growth, sporulation and germination in vitro}

Five homeopathic drugs were selected to test their capability to inhibit Aspergillus niger growth in vitro, the phytopathogenic agent responsible for sisal red rot. Each homeopathic drug exhibited different response on Aspergillus niger growth, sporulation, germination, and viable spores in vitro and accordingly to the dynamizations tested $(3 \mathrm{CH}, 5 \mathrm{CH}, 7 \mathrm{CH}, 9 \mathrm{CH}$ and $12 \mathrm{CH}$ ). Figure 2 represents the growth inhibition caused by the five homeopathic drugs tested at different dynamizations. Positive values represent those dynamizations that did not inhibit Aspergillus niger in vitro growth comparatively to control treatment. Negative values represent dynamizations which were effective against Aspergillus niger, inhibiting its growth. The following presented the dynamizations which inhibited significantly Aspergillus niger growth in vitro by increasing order: sulphur $5 \mathrm{CH}(6.4 \%)<$ phosphorus $9 \mathrm{CH}$ and $3 \mathrm{CH}$ (14 and $21 \%$, respectively) $<$ Carbo vegetabilis $12 \mathrm{CH}$ and $7 \mathrm{CH}(27$ and $34 \%$, respectively) $<$ sulphur $9 \mathrm{CH}(36 \%)<$ Ferrum metallicum $9 \mathrm{CH}(44 \%)<$ Natrum muriaticum 5CH (66 \%) (Fig. 2). The responses obtained for each homeopathic drug, among the different dynamizations tested, were in "V" shape, according to the previously achieved by Kolisko and Kolisko (1978), where the dynamizations tested inside a same homeopathic drug sometimes stimulate or inhibit the mycelial growth, sporulation and germination. The obtained results also respect the homeopathic principles of similitude, pathogenesis and experiments in healthy specimens (Hahnemann 1842).

Concerning Carbo vegetabilis dynamizations, $5 \mathrm{CH}$ and 9 $\mathrm{CH}$ reported no significant effects on Aspergillus niger, stimulating its growth at $7.8 \%$ comparatively to control treatments. The lowest dynamization, $3 \mathrm{CH}$, did not cause any impact in Aspergillus niger growth. Carbo vegetabilis was reported as an inhibiting homeopathic drug for other Aspergillus species, namely Aspergillus parasiticus (Bee and Atri 2013), with inhibiting rates of 63 and $70 \%$ respectively at $6 \mathrm{CH}$ and $12 \mathrm{CH}$. Another important fact is that this homeopathic drug was able to reduce the production of aflatoxin B1, toxic when ingested in contaminated food by humans (Williams et al. 2004). For Ferrum metallicum dynamizations, $7 \mathrm{CH}$ and $12 \mathrm{CH}$ reported no effect on Aspergillus niger growth comparatively to control, while $3 \mathrm{CH}$ and $5 \mathrm{CH}$ stimulated Aspergillus niger growth by 17 and $20 \%$, respectively. In the remaining homeopathic drugs tested, it was observed that those dynamizations that did not inhibit Aspergillus niger reported a neutral activity, so they did not improve Aspergillus niger growth as well. In all the homeopathic drugs, in the dynamizations where it was observed, a stimulation in Aspergillus niger growth observed an increase in the first 2 days after inoculation, being observed a considerable drawback afterwards comparatively to Aspergillus niger growth in control treatments (Fig. 2). Such observation highlights the possible long-term effect of the potentialities of homeopathic drugs.

Some of the homeopathic drugs tested in the resent study were also effective against other fungus. For instance, sulphur was effectively applied in the inhibition growth of Aspergillus parasiticus at 200CH (Sinha and Singh 1983), on the same way as Carbo vegetabilis (Bee and Atri 2013), reducing aflatoxin production in about $100 \%$ in stored products. sulphur was also able to inhibit mycelial growth of Silicea and Dulcamara fungus in $50 \%$, reducing toxin production in about $90 \%$ (Sinha and Singh 1983).

Regarding sporulation, it was not inhibited by any homeopathic drug tested at the dynamizations assayed in this work, being spore production stimulated relatively to control treatments (Table 1). Regarding average values, spore production was stimulated about $30 \%$ in Carbo vegetabilis application, $64 \%$ in phosphorus, $97 \%$ in sulphur, $136 \%$ in Natrum muriaticum and $140 \%$ in Ferrum metallicum. From these results presented in Table 1, the main observation can be inferred that each homeopathic drug dynamizations caused a high growth inhibition activity result, generally, in lower spore production.

Contrary to sporulation, all homeopathic drugs reduced the percentage of germinated spores comparatively to control treatment, as reported in Table 1. Carbo vegetabilis was able to reduce significantly $(P<0.001)$ spore germination at $3 \mathrm{CH}$ and $5 \mathrm{CH}$, with 49 and $36 \%$ inhibition, respectively. Ferrum metallicum also inhibited significantly the spore germination at all dynamizations $(P<0.001)$ being those at $3 \mathrm{CH}$ and $9 \mathrm{CH}$ that reported higher conidia germination inhibition (47 and $23 \%$, respectively, comparatively to control treatment). Natrum muriaticum dynamization of $5 \mathrm{CH}$ did not differ 
Fig. 2 Growth inhibition (\%) of Aspergillus niger in vitro by different homeopathic drugs at different dynamizations. Growth of $A$. niger was considerably reduced at $7 \mathrm{CH}$ and $12 \mathrm{CH}$ in Carbo vegetabilis, at $9 \mathrm{CH}$ in Ferrum metallicum and sulphur, at $5 \mathrm{CH}$ in Natrum muriaticum and at $3 \mathrm{CH}$ and $9 \mathrm{CH}$ in phosphorus. Higher growth inhibition was observed with application of Natrum muriaticum
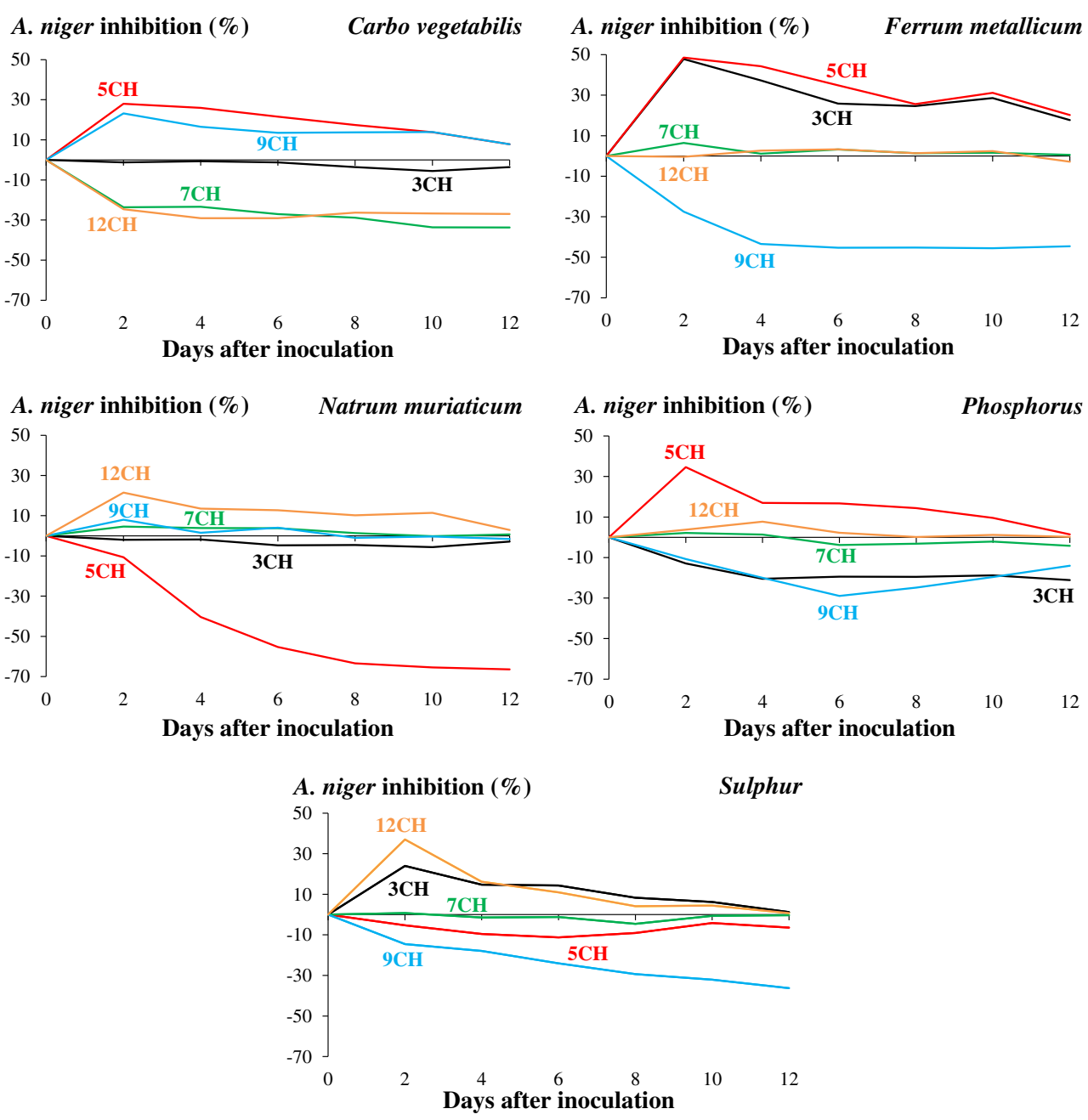

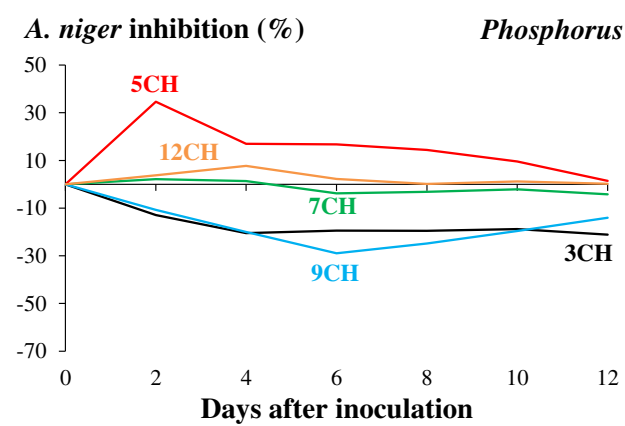

Sulphur significantly from control treatments, while the remaining dynamizations inhibited significantly spore germination in about $30 \%$ (Table 1). In phosphorus and Ferrum metallicum, all dynamizations tested inhibited spore germination varying between $28 \%$ in $5 \mathrm{CH}$ and $7 \mathrm{CH}$ and $58 \%$ in $12 \mathrm{CH}$. In sulphur, four dynamizations also inhibited spore germination comparatively to control treatments, being $5 \mathrm{CH}, 7 \mathrm{CH}$ and $12 \mathrm{CH}$ the dynamizations that reported higher spore germination, approximately $50 \%$.

The number of viable spores was also obtained. Considerable lower number of viable spores was observed in sulphur $5 \mathrm{CH}$. The number of spores produced was very low at that dynamization comparatively to control and other dynamizations tested. On the other hand, the germination rate was also low; therefore, only $1.1 \times 10^{-7}$ million spores were able to germinate (Table 1), lower than control. Carbo vegetabilis was more effective in reducing the viable number of spores at $3 \mathrm{CH}$, being also the most effective dynamization in Ferrum metallicum. With phosphorus application, lower numbers of viable spores were counted at $12 \mathrm{CH}$ (Table 1).
It is clear that the application of homeopathic drugs in Aspergillus niger causes significant effects on their dissemination, playing as biocide agents. Two important aspects were observed in in vitro assays: (i) growth inhibition and (ii) increase in sporulation. This fact could be the response of Aspergillus niger to aggression in order to achieve stress adaptation (Russell 2003) that could imply cell wall reinforcement to reduce or inhibit the entrance of hazardous agents. These defence mechanisms trigger the expression of several genes responsible for the activation of important enzymes for the solidification of cell wall (Damveld et al. 2005; Ram et al. 2004) and deposition of chitin.

During the contact with the homeopathic drugs, Aspergillus niger induced the production of spores as a survival mechanism. Nevertheless, in many dynamizations tested, the number of viable spores was considerably reduced comparatively to control (Table 1). In the case of sulphur $5 \mathrm{CH}$ despite the great number of spores produced, the number of viable spores comparatively to control was reduced by half. 
Table 1 In vitro sporulation (millions of spores), germination $(\%)$ and viable spores (millions of spores) of Aspergillus niger according to the different homeopathic drugs applied at different dynamizations
Mean values with different letters, in each parameter evaluated, for each homeopatic drug tested at different dynamizations, differ significantly $(\mathrm{P}<0.05)$

\begin{tabular}{|c|c|c|c|c|}
\hline Treatment applied & & Sporulation & Germination & Viable spores \\
\hline \multirow[t]{5}{*}{ Carbo vegetabilis } & $3 \mathrm{CH}$ & $36.15 \pm 2.4 \mathrm{~b}$ & $39.75 \pm 3.10 \mathrm{~b}$ & $1.4 \times 10^{-7} \pm 1.6 \times 10^{-6} \mathrm{a}$ \\
\hline & $5 \mathrm{CH}$ & $61.28 \pm 9.36 \mathrm{c}$ & $50.00 \pm 10.2 \mathrm{a}$ & $3.1 \times 10^{-7} \pm 9.3 \times 10^{-6} \mathrm{~b}$ \\
\hline & $7 \mathrm{CH}$ & $32.12 \pm 4.74 \mathrm{~b}$ & $76.00 \pm 3.92 \mathrm{a}$ & $2.4 \times 10^{-7} \pm 3.7 \times 10^{-6} \mathrm{a}, \mathrm{b}$ \\
\hline & $9 \mathrm{CH}$ & $30.63 \pm 4.46 \mathrm{a}, \mathrm{b}$ & $75.00 \pm 12.11 \mathrm{~b}$ & $2.3 \times 10^{-7} \pm 5.4 \times 10^{-6} \mathrm{a}, \mathrm{b}$ \\
\hline & $12 \mathrm{CH}$ & $19.11 \pm 2,93 \mathrm{a}$ & $79.25 \pm 16.64 \mathrm{~b}$ & $1.5 \times 10^{-7} \pm 5.0 \times 10^{-6} \mathrm{a}$ \\
\hline Control & - & $27.40 \pm 3.99 \mathrm{a}, \mathrm{b}$ & $78.60 \pm 1.74 \mathrm{~b}$ & $2.2 \times 10^{-7} \pm 3.1 \times 10^{-6} \mathrm{a}$ \\
\hline \multirow[t]{5}{*}{ Ferrum metallicum } & $3 \mathrm{CH}$ & $42.68 \pm 4.86 \mathrm{a}$ & $41.31 \pm 4.89 \mathrm{a}$ & $1.7 \times 10^{-7} \pm 1.3 \times 10^{-6} \mathrm{a}$ \\
\hline & $5 \mathrm{CH}$ & $60.23 \pm 2.27 \mathrm{~b}$ & $49.08 \pm 5.19 \mathrm{a}, \mathrm{b}$ & $3.0 \times 10^{-7} \pm 3.5 \times 10^{-6} \mathrm{~b}, \mathrm{c}$ \\
\hline & $7 \mathrm{CH}$ & $87.63 \pm 9.06 \mathrm{c}$ & $53.46 \pm 9.13 \mathrm{a}, \mathrm{b}$ & $4.6 \times 10^{-7} \pm 4.8 \times 10^{-6} \mathrm{~d}$ \\
\hline & $9 \mathrm{CH}$ & $59.88 \pm 9.97 \mathrm{~b}$ & $59.87 \pm 9.30 \mathrm{~b}$ & $3.6 \times 10^{-7} \pm 6.4 \times 10^{-6} \mathrm{c}, \mathrm{d}$ \\
\hline & $12 \mathrm{CH}$ & $79.54 \pm 10.63 \mathrm{c}$ & $53.50 \pm 9.33 \mathrm{a}, \mathrm{b}$ & $4.2 \times 10^{-7} \pm 8.5 \times 10^{-6} \mathrm{~d}$ \\
\hline Control & - & $27.40 \pm 3.99 \mathrm{a}$ & $78.60 \pm 1.74 \mathrm{c}$ & $2.2 \times 10^{-7} \pm 3.1 \times 10^{-6} \mathrm{a}, \mathrm{b}$ \\
\hline \multirow[t]{5}{*}{ Natrum muriaticum } & $3 \mathrm{CH}$ & $86.64 \pm 7.72 \mathrm{~d}$ & $58.00 \pm 11.31 \mathrm{a}$ & $5.0 \times 10^{-7} \pm 1.2 \times 10^{-7} \mathrm{~b}$ \\
\hline & $5 \mathrm{CH}$ & $34.62 \pm 5.07 \mathrm{a}, \mathrm{b}$ & $63.00 \pm 9.93 \mathrm{a}, \mathrm{b}$ & $2.2 \times 10^{-7} \pm 6.8 \times 10^{-6} \mathrm{a}$ \\
\hline & $7 \mathrm{CH}$ & $48.65 \pm 6.70 \mathrm{~b}, \mathrm{c}$ & $57.75 \pm 6.18 \mathrm{a}$ & $2.8 \times 10^{-7} \pm 5.8 \times 10^{-6} \mathrm{a}$ \\
\hline & $9 \mathrm{CH}$ & $93.54 \pm 8.23 \mathrm{~d}$ & $51.43 \pm 9.92 \mathrm{a}$ & $4.8 \times 10^{-7} \pm 6.3 \times 10^{-6} \mathrm{~b}$ \\
\hline & $12 \mathrm{CH}$ & $60.23 \pm 9.75 \mathrm{c}$ & $52.00 \pm 4.97 \mathrm{a}$ & $3.1 \times 10^{-7} \pm 5.3 \times 10^{-6} \mathrm{a}$ \\
\hline Control & - & $27.40 \pm 3.99 \mathrm{a}$ & $78.60 \pm 1.74 b$ & $2.2 \times 10^{-7} \pm 3.1 \times 10^{-6} \mathrm{a}$ \\
\hline \multirow[t]{5}{*}{ Phosphorus } & $3 \mathrm{CH}$ & $39.79 \pm 0.43 \mathrm{a}, \mathrm{b}$ & $46.50 \pm 9.75 \mathrm{a}, \mathrm{b}$ & $1.9 \times 10^{-7} \pm 3.9 \times 10^{-6} \mathrm{a}$ \\
\hline & $5 \mathrm{CH}$ & $48.81 \pm 7.14 \mathrm{~b}$ & $56.25 \pm 7.85 \mathrm{~b}$ & $2.7 \times 10^{-7} \pm 4.1 \times 10^{-6} \mathrm{a}$ \\
\hline & $7 \mathrm{CH}$ & $45.35 \pm 6.82 \mathrm{~b}$ & $56.50 \pm 13.48 \mathrm{~b}$ & $2.6 \times 10^{-7} \pm 9.2 \times 10^{-6} \mathrm{a}$ \\
\hline & $9 \mathrm{CH}$ & $38.65 \pm 7.06 \mathrm{a}, \mathrm{b}$ & $49.00 \pm 9.06 \mathrm{a}, \mathrm{b}$ & $1.9 \times 10^{-7} \pm 2.9 \times 10^{-6} \mathrm{a}$ \\
\hline & $12 \mathrm{CH}$ & $62.66 \pm 8.42 \mathrm{~b}$ & $33.00 \pm 6.78 \mathrm{a}$ & $1.8 \times 10^{-7} \pm 6.0 \times 10^{-6} \mathrm{a}$ \\
\hline Control & - & $27.40 \pm 3.99 \mathrm{a}$ & $78.60 \pm 1.74 \mathrm{c}$ & $2.2 \times 10^{-7} \pm 3.1 \times 10^{-6} \mathrm{a}$ \\
\hline \multirow[t]{5}{*}{ Sulphur } & $3 \mathrm{CH}$ & $74.16 \pm 10.74 \mathrm{c}$ & $61.25 \pm 14.06 \mathrm{~b}, \mathrm{c}$ & $4.5 \times 10^{-7} \pm 1.1 \times 10^{-7} \mathrm{~b}$ \\
\hline & $5 \mathrm{CH}$ & $31.56 \pm 4.85 \mathrm{a}$ & $34.50 \pm 4.65 \mathrm{a}$ & $1.1 \times 10^{-7} \pm 2.4 \times 10^{-6} \mathrm{a}$ \\
\hline & $7 \mathrm{CH}$ & $56.59 \pm 9.28 \mathrm{c}$ & $41.00 \pm 5.94 \mathrm{a}$ & $2.3 \times 10^{-7} \pm 6.4 \times 10^{-6} \mathrm{a}$ \\
\hline & $9 \mathrm{CH}$ & $53.72 \pm 8.47 \mathrm{~b}$ & $47.00 \pm 10.74 \mathrm{a}, \mathrm{b}$ & $2.5 \times 10^{-7} \pm 3.1 \times 10^{-6} \mathrm{a}$ \\
\hline & $12 \mathrm{CH}$ & $54.78 \pm 7.72 b$ & $41.75 \pm 7.41 \mathrm{a}$ & $2.3 \times 10^{-7} \pm 6.0 \times 10^{-6} \mathrm{a}$ \\
\hline Control & - & $27.40 \pm 3.99 \mathrm{a}$ & $78.60 \pm 1.74 \mathrm{c}$ & $2.2 \times 10^{-7} \pm 3.1 \times 10^{-6} \mathrm{a}$ \\
\hline
\end{tabular}

Khanna and Chandra (1978) evaluated the effects of homeopathic treatments over the mycelial growth, sporulation and spore germination of Alternaria alternata isolated from apple and tomato, Gibberella zeae isolated from banana and tomato, Glomerella cingulata and Pestalotiopsis mangiferae isolated from mango, and Pestalotiopsis psidii and Colletotrichum coccodes isolated from guava. These authors checked that the homeopathic drugs were effective over the fungus spore germination and founded a positive correlation between spore germination and mycelial growth, mainly in centesimal dynamizations. Khanna et al. (1989) by studying wheat seeds, verified that Fusarium oxysporum population was inhibited at $30 \mathrm{CH}$ and $200 \mathrm{CH}$ and Alternaria alternata at $3 \mathrm{CH}, 6 \mathrm{CH}$, $30 \mathrm{CH}$ and $200 \mathrm{CH}$ of Blatla orientalis homeopathic drug, however, without influencing seed germination. In other study, Khanna (1993) verified that the dynamizations $3 \mathrm{CH}$, $6 \mathrm{CH}, 30 \mathrm{CH}$ and $200 \mathrm{CH}$ of homeopathic drugs Lycopodium clavatum and Thuya occidentalis inhibited the populations of
Fusarium oxysporum from wheat seeds microflora and from roots surface.

Table 2 Incidence (\%) of Aspergillus niger in planta sisal plants and disease severity index (DSI \%)

\begin{tabular}{lll}
\hline Treatment applied & Incidence & DSI \\
\hline Control & $91.67 \pm 9.62$ & $73.61 \pm 13.13 \mathrm{~b}$ \\
Carbo vegetabilis 12CH & $83.33 \pm 13.61$ & $72.22 \pm 21.28 \mathrm{~b}$ \\
Ferrum metallicum 9CH & $66.67 \pm 23.57$ & $27.77 \pm 7.85 \mathrm{a}$ \\
Phosphorus 3CH & $70.83 \pm 20.97$ & $48.61 \pm 20.47 \mathrm{a}, \mathrm{b}$ \\
Natrum muriaticum 5CH & $62.50 \pm 28.46$ & $64.81 \pm 22.45 \mathrm{a}, \mathrm{b}$ \\
Sulphur 5CH & $87.50 \pm 8.33$ & $73.61 \pm 19.96 \mathrm{~b}$ \\
$P$ value & 0.142 & 0.016
\end{tabular}

Mean values with different letters, in each parameter evaluated, for each homeopatic drug tested at different dynamizations, differ significantly $(\mathrm{P}<0.05)$

$D S I$ disease severity index 
According to the results obtained by Mishra (1983), by testing different homeopathic drugs in the mycelial growth and spore germination of Aspergillus niger, which cause damages in stored seeds of Coriandrum sativum and Cuminum cyminum, it was observed that Arsenicum album, Calcarea carbonica, Graphites and phosphorus induced fungus inhibition in more than $90 \%$ comparatively to control treatments.

\subsection{In planta assays}

Based on the parameters evaluated in vitro (growth inhibition, spore production and percentage of germinated spores), one dynamization was elected per homeopathic drug tested to perform in planta assays in greenhouses. The selected dynamizations were Carbo vegetabilis-12CH; Ferrum metallicum-9 $\mathrm{CH}$; phosphorus-3CH; Natrum muriaticum $-5 \mathrm{CH}$; and sulphur $-5 \mathrm{CH}$. In relation to sisal red rot disease incidence, no significant effects were observed in the application of homeopathic drugs comparatively to control treatments $(P=0.142$; Table 2$)$. In control treatment, $91.67 \%$ of plants revealed disease symptoms, while in Ferrum metallicum $9 \mathrm{CH}$ and Natrum muriaticum $5 \mathrm{CH}$, only 66.67 and $62.50 \%$ of the plants were infested, revealing the disease symptoms (Table 2). Sulphur 5CH, among the homeopathic drugs tested, was the one that exhibited higher disease incidence in greenhouse plants, $87.50 \%$.

Besides high levels of disease incidence, the disease severity results were encouraging, since the disease stages were kept at low instance (Table 2). When treated with Ferrum metallicum $9 \mathrm{CH}$ plants, disease severity was significantly reduced ( $P=0.0159)$ by $62 \%$ comparatively to control treatments. Applications of Natrum muriaticum $5 \mathrm{CH}$ and phosphorus $3 \mathrm{CH}$ were not statistically different from Ferrum metallicum; however, they did not differ also from control treatments. Natrum muriaticum homeopathic drug at $5 \mathrm{CH}$ revealed in vitro activity against Aspergillus niger mycelial growth, meanwhile such effect was not representative in planta. Bee and Atri (2013) reported that homeopathic drugs at same dynamizations showed different results in vitro and in vivo with relation to the production of aflatoxins in peanut seeds. The same authors found that while some homeopathic drugs at different dynamizations inhibit A. parasiticus in vivo, evaluated by the production of aflatoxin $\mathrm{B} 1$, they were incapable to control the mycelial growth in vitro.

Shah-Rossi et al. (2009) by evaluating the in vivo application of homeopathic drugs in Arabidopsis thaliana infected by Pseudomonas syringae observed that Carbo vegetabilis $30 \mathrm{CH}$, sulphur $30 \mathrm{CH}$ and Magnesium phosphoricum $30 \mathrm{CH}$ reduced the infection rate in Arabidopsis thaliana by $P$. syringae.

Carneiro et al. (2010) discovered that the application of biotherapic of Alternaria solani at $27 \mathrm{CH}$ and $28 \mathrm{CH}$ controls the blight of tomato plant in 57 and $62 \%$, respectively, in greenhouses, and besides that no studies were conducted over mycelial growth and spore germination.

\section{Conclusions}

The use of homeopathic drugs Carbo vegetabilis, Natrum muriaticum, Ferrum metallicum, sulphur and phosphorus at different dynamizations inhibited the mycelial growth and spore germination of Aspergillus niger. From in planta studies, we concluded that disease incidence is lowly reduced; however, disease severity is deeply affected, inhibiting the propagation of the phytopathogenic agent in sisal plants, reducing considerably the development inside the plant. In order to achieve more deep and conclusive data, the next step will be to evaluate the current homeopathic drugs in field conditions to evaluate in real conditions their capability to protect sisal plants from Aspergillus niger, the causal agent of red rot.

Other important conclusion is that the application of homeopathic drugs may be a good strategy to diminish or even replace synthetic products in the future, being possible the practice of a more sustainable and eco-friendly agriculture.

Acknowledgments This study was supported by grants from the "Conselho Nacional de Desenvolvimento Científico e Tecnológico" through the Project "Tecnologia Social na Inclusão Sócio Produtiva dos Agricultores Familiares da Cultura do Sisal”.

\section{References}

Bee S, Atri DC (2013) Inhibitory effect of homeopathic drugs on the production of aflatoxin B1 in groundnuts. Int J Pharm Pharm Sci 5: 73-75

Betti L, Trebbi G, Majewsky V, Schen C, Shah-Rossi D, Jäger T, Baumgartner S (2009) Use of homeopathic preparations in phytopathological models and in field trials: a critical review. Homeopathy 98:244-266. doi:10.1016/j.homp.2009.09.008

Betti L, Trebbi G, Olioso D, Marzoto M, Bellavite P (2013) Basic research in homeopathy and ultra-high dilutions: what progress is being made? Homeopathy 102:151-154. doi:10.1016/j.homp.2013.01.002

Bonato CM, Viotto EG, Hara JH, Reis B, Myzote AT, Cisneiros JA (2006) The application of the homeopathic drugs Lachesis and Isotherarapic Virus in the growth and infection control for SCMV in sorghum Moench) (Sorghum bicolor (L.) Moench). Cultura Homeopática Arquivos da Escola de Homeopatia 16:51

Carneiro SMTPG, Romano EDB, Pignoni E, Teixeira MZ, Vasconcelos MEC, Gomes JC (2010) Effect of biotherapic of Alternaria solani on the early blight of tomato-plant and the in vitro development of the fungus. Int J High Dilution Res 33:147-155

Casali VWD, Andrade FMC, Duarte ESM (2009) Acologia de Altas Diluições. Resultados científicos e experiências sobre o uso de preparados homeopáticos em sistemas vivos. Imprensa Universitária da Universidade Federal de Viçosa, Viçosa

Chaurasia JP, Vyas KM (1997) In vivo evaluation of some homoeopathic drugs against betelvine Phytophthora disease. Indian Phytopathol 50:542-547

Coutinho WM, Suassuna ND, Luz CM, Suinaga FA, Silva ORRF (2006) Bole rot of sisal caused by Aspergillus niger in Brazil. Fitopatol Bras 31:605. doi:10.1590/S0100-41582006000600014 
Damveld RA, Arentshorst M, Franken A, vanKuyk PA, Klis FM, van den Hondel CAMJJ, Ram AFJ (2005) The Aspergillus niger MADSbox transcription factor RImA is required for cell wall reinforcement in response to cell wall stress. Mol Microbiol 58:305-319. doi:10. 1111/j-1365-2958.2005.04827.x

FAO (2014) FAO STAT database. http://faostat.fao.org/. Accessed 24 Mar 2014 FHB (2011) Farmacopéia Homeopática Brasileira, 3rd edn. Brasília

Gutiérrez A, Rodríguez IM, Río JC (2008) Chemical composition of lipophilic extractives from sisal (Agave sisalana) fibers. Ind Crop Prod 28:81-87. doi:10.1016/j.indcrop.2008.01.008

Hahnemann (1842) Organon of medicine. Translated from German 6th Edition by Castro C, Filho R, Curi K (1995) 2nd Brazilian Edition. São Paulo. GEHSP, Benoit Mure

IBGE SIDRA (2014) Instituto Brasileiro de Geografia e Estatística. Sistema IBGE de Recuperação Automática. http://www.sidra.ibge. gov.br/. Accessed 27 Mar 2014

Javed MT, Khan MA, Ehetisham-ul-Haq M, Atiq M (2013) Biological management of bacterial blight of cotton caused by Xanthomonas campestris pv. malvacearum through plant extracts and homeopathic products. Res J Plant Dis Pathol 1:1-10

Kehri KH, Chandra S (1986) Control of Botryodiplodia rot of guava with a homeopathic drug. Natl Acad Sci Lett 9:301-302

Khanna KK (1993) Suppression of Fusarium oxysporum Schlecht a pathogen causing seedling blight and foot rot of wheat, with homoeopathic drugs. Natl Acad Sci Lett 63:353-360

Khanna KK, Chandra S (1978) A homeopathic drug controls mango fruit rot caused by Pestalotia magnifaere Henn. Experientia 34:1167-1168

Khanna KK, Khanna KK, Chandra S (1989) Effect of homoeopathic drugs on seed mycoflora of wheat. Natl Acad Sci Lett 12:39-41

Kolisko E, Kolisko L (1978) Agriculture of tomorrow. Acorn Press, Bournemouth

McKinney HH (1925) Influence of soil temperature and moisture on infection of wheat seedlings by Helminthosporium sativum. J Agric Res 26:195-218
Mishra N (1983) Inhibition of Aspergillus niger van Tiegh. By homeopathic drugs causing deterioration of coriander and cumin seeds in storage. Natl Acad Sci Lett 6:139-141

Ram AFJ, Arentshorst M, Damveld RA, vanKuyk PA, Klis FM, van den Hondel CAMJJ (2004) The cell wall stress response in Aspergillus niger involves increased expression of the glutamine:fructose-6-phosphate amidotransferase-encoding gene $(g f a A)$ and increased deposition of chitin in the cell wall. Microbiology 150:3315-3326

Russell AD (2003) Similarities and differences in the response of microorganisms to biocides. J Antimicrob Chemother 52:750-763. doi: 10.1093/jac/dkg422

Sá JO (2009) Patogênese de Aspergillus niger e biocontrole da podridão vermelha do sisal por Trichoderma spp. Dissertation, Universidade Federal do Recôncavo da Bahia

Shah-Rossi D, Heusser P, Baumgartner S (2009) Homeopathic treatment of Arabidopsis thaliana plants infected with Pseudomonas syringae. Sci World J 9:323-330. doi:10. 1100/tsw.2009.38

Sinha KK, Singh P (1983) Homeopathic drugs - inhibitors of growth and aflatoxin production by Aspergillus parasiticus. Indian Phytopathol 36:356-357

Toledo MV, Stangarlin JR, Bonato CM (2011) Homeopathy for the control of plant pathogens. In: Méndez-Vilas A (ed) Science against microbial pathogens: communicating current research and technological advances, vol 2. Formatex Research Center, Badajoz, pp 1063-1067

Williams JH, Phillips TD, Jolly PE, Stiles JK, Jolly CM, Aggarwal D (2004) Human aflatoxicosis in developing countries: a review of toxicology, exposure, potential health consequences, and intervention. Am J Clin Nutr 80:1106-1122

Wyss E, Tamm L, Siebenwirth J, Baumgartner S (2010) Homeopathic preparations to control the rosy apple aphid (Dysaphis plantaginea Pass.). Sci World J 10:38-48. doi:10.1100/tsw.2010.12 